\title{
Genomics, Domestication, and Evolution of Forest Trees
}

\author{
R. SEDERofF, ${ }^{1}$ A. Myburg, ${ }^{2}$ AND M. KIRST ${ }^{3}$ \\ ${ }^{1}$ Forest Biotechnology Group, North Carolina State University, Raleigh, North Carolina 27695; ${ }^{2}$ Department of \\ Genetics, Forestry and Agricultural Biotechnology Institute, University of Pretoria, Pretoria, 0002, South Africa; \\ ${ }^{3}$ School of Forest Resources and Conservation, University of Florida, Gainesville, Florida 32611 \\ Correspondence: ron_sederoff@ncsu.edu
}

\begin{abstract}
The forests of the world continue to be threatened by climate change, population growth, and loss to agriculture. Our ability to conserve natural forests and to meet the increasing demand for fuel, biomass, wood, and paper depends on our fundamental understanding of tree growth and adaptation (FAO 2001; Fenning and Gershenzon 2002; Campbell et al. 2003; Gray et al. 2006). Our knowledge of the unique biology of trees will be greatly advanced through the application of genomics. The purpose of this chapter is to describe this emergent genomic paradigm as it is being applied to trees.
\end{abstract}

Genomics provides a platform to learn the relationships of genes and phenotypes and to integrate molecular and quantitative genetics for the analysis of adaptive traits (Frewen et al. 2000; Wullschleger et al. 2002; Brunner et al. 2004). Genomics provides answers to fundamental questions of tree biology and addresses practical problems in tree plantations, forest management, and conservation. Genomic association of natural allelic variation with improved growth and wood properties is being incorporated into tree-breeding programs through allele-specific evaluation and selection (Neale 2007; Grattapaglia et al. 2009). The following are four main areas of genomerelated investigation in forest trees.

1. Fundamental biology of growth, metabolism, and development. Genomic analysis elucidates the mechanisms regulating the vascular cambium, the lateral meristem (stem cell layer) that produces wood. There is also considerable interest in the control of flowering and dormancy, because of the adaptive significance of these traits. Abundant flowering and short growing seasons reduce wood yield and biomass. The ability to induce flowering can accelerate breeding.

2. Abiotic stress. Our understanding of the mechanisms of tree responses to abiotic stress can be expanded by genomic analysis. Stresses may be due to water and temperature or the effects of environmental chemistry or environmental pollution. Abiotic stress is a major consequence of climate change, and the understanding of the genetic architecture of stress responses is essential for predicting adaptation in forests.

3. Pests and pathogens. Understanding the interactions of trees with their symbionts, pathogens, and pests is important for predicting the biological consequences of climate change and for developing more tolerant plantation trees. Trees, pathogens, and pests are coevolving systems that often determine the fates of their ecosystems. Pest and pathogen interactions can now be explored at a genomic level to ameliorate ecosys- tem threats (Steiner and Carlson 2004; Ralph et al. 2006a,b; Whitham et al. 2006).

4. Adaptation and evolution. Genomics provides valuable information about genetic diversity of trees, its distribution, and effects on adaptation and evolution (Neale and Ingvarsson 2008). This knowledge is being applied to forest management and conservation in the context of past history and predicted change in climate.

Molecular genetic studies of forest trees have followed three main approaches: (1) Comparative analysis of trees with Arabidopsis and model crops has been used to identify functional genetic conservation and to expand our understanding of the similarities and differences between woody and herbaceous plants. (2) Transgenic technology in trees has allowed a reverse genetics approach, using activation or suppression of gene expression to investigate function. (3) Forward genetics approaches, based on quantitative and qualitative analysis of natural variation, have been used to understand the genetic architecture and molecular basis of specific traits.

\section{FOREST TREE DIVERSITY AND DOMESTICATION}

In contrast to many of our herbaceous crops that have been bred and selected for thousands of generations, forest trees are essentially undomesticated. They are also characterized by high genetic diversity and high genetic load (Hamrick et al. 1992; Remington and O’Malley 2000). An exception, red pine, exhibits low genetic diversity, attributed to a bottleneck in its recent evolution (DeVerno and Mosseler 1997). Clones of quaking aspen (Populus tremuloides) are found in massive monoclonal stands, consisting of tens of thousands of genetically identical trees, all connected through a massive underground root system. One such clone has been described as the largest single plant and potentially the largest organism on earth (Mitton and Grant 1996). 
The high levels of genetic diversity can be exploited for tree breeding (Zobel and Talbert 1984). Trees used for plantation forestry are very much like their natural counterparts. Early domestication in annual crops such as maize is thought to have involved relatively small numbers of genetic events (Doebley et al. 1997; Doebley and Lukens 1998), followed by rapid changes in allele frequencies at loci that affect plant architecture and biochemistry (Lev-Yadun et al. 2002; Jaenicke-Després et al. 2003; J. Doebley, pers. comm.). Major genetic changes of a kind that have accompanied domestication of cereals, for example, have not yet occurred in forest trees. It is not yet clear what kind of genetic changes might become associated with tree domestication (Boerjan 2005).

\section{WOOD DEVELOPMENT AND EVOLUTION}

Wood provides the basis for the mechanical support and water transport that allow trees to attain great age and size. Wood formation (xylogenesis) takes place through cell division and differentiation of the vascular cambium, a secondary lateral meristem in the stems, branches, and roots of woody plants. Cambial initials divide and differentiate into a vertical support and water transport system consisting of tracheids in gymnosperms or fibers and vessels in angiosperms. A lateral transport system is predominantly composed of rays (Larson 1994). Growth rate slows as trees age, thought to be a consequence of the physiological burden of increasing size (Mencuccini et al. 2007). With abundant water and nutrients, absence of biotic and abiotic stresses, and competition for light, trees may have the potential to grow as high as $120 \mathrm{~m}$ (Koch et al. 2004). The current tallest tree-a costal redwood(Hyperion) is $115 \mathrm{~m}$. Records of Eucalyptus regnans from the 19th century exceed this height by more than $30 \mathrm{~m}$.

Vascular plants are derived from a rootless leafless freshwater filamentous alga in the genus Cooksonia, $\sim 400$ million years ago (mya) (Chaloner and Macdonald 1980). Five extant plant lines derived from this early ancestor are separated into two major groups, the angiosperms and the gymnosperms (Fig. 1). The five lines are the Gnetales, cycads, ginkgos, conifers (all gymnosperms), and angiosperms (Qui et al. 2007). Angiosperms and gymnosperms last shared a common ancestor $\sim 300$ mya (Bowe et al. 2000). The angiosperms include the largest number $(250,000+)$ and the most diverse number of species, with both herbaceous and woody plants, and include all the major food crops. The gymnosperms include only $\sim 1000$ species, but a small number of those dominate many of the Northern hemisphere's temperate forests. All gymnosperms are woody plants.

Small numbers of genetic changes may be involved in the transition between herbaceous and woody plants. DNA sequence relationships support the relatively recent evolution of woody plants found on islands descending from continental herbaceous founders (Böhle et al. 1996; Helfgott et al. 2000). Arabidopsis thaliana, typically small, fast growing, and herbaceous, can be induced to form secondary xylem (wood) by delaying flowering and senescence (Lev-Yadun 1994; Dolan and Roberts 1995; Chaffey et al. 2002). The genes that determine the woody growth habit appear not to be unique to woody plants but are likely to be common genes, regulated in different ways (Groover 2005). A suite of transcription factors that regulate secondary cell wall formation in xylem vessel and fiber cells have recently been characterized in Arabidopsis (Zhong et al. 2008) and may perform similar functions in woody plants.

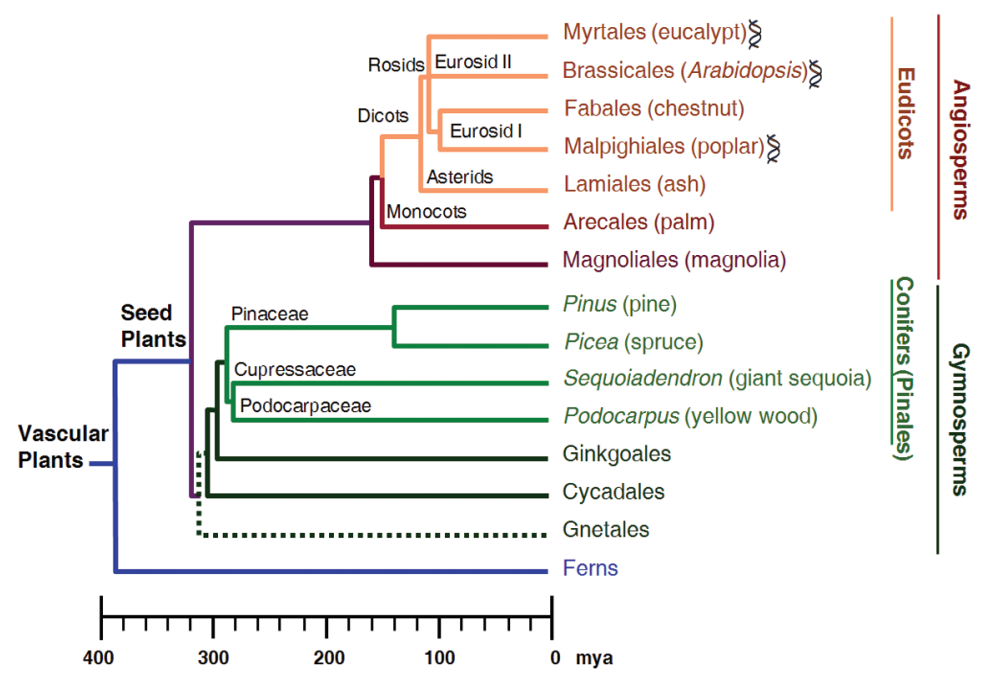

Figure 1. Simplified phylogeny of the major groups of woody plants. Species for which genome sequencing has been completed, or is under way, are indicated by DNA helices. The position of the Gnetales in the seed plant phylogeny has not been resolved. Some studies place Gnetales as a sister group to the Coniferales or the Pinaceae, but a phytochrome phylogeny placed it at the base of the gymnosperms (Chaw et al. 2000; Magallón and Sanderson 2002; Schmidt and Schneider-Poetsch 2002; Burleigh and Mathews 2004; de la Torre et al. 2006). 


\section{APPLICATION OF GENOMICS IN FOREST TREES}

Although they are large, unwieldy, and have long generation times, many features of trees make them suitable for genomic studies. Trees provide excellent material for genome-wide studies of adaptation and evolution in natural populations. Genomics has also provided insight into the molecular basis of tree growth (Kirst et al. 2004a; Poke et al. 2005; Grattapaglia et al. 2009), development (Hertzberg et al. 2001; Schrader et al. 2004; Ko et al. 2006), adaptation (Yang and Loopstra 2005), and the evolution of herbaceous and woody growth habits (Kirst et al. 2003; Tuskan et al. 2006). The molecular basis of wood formation, the chemical diversity of woody plants, and the basis for extensive longevity in forest trees are topics being addressed. Genomics has also provided a paradigm for the investigation of the molecular basis of complex traits in forest trees, by associating genotype with phenotype. A more complete understanding of this relationship leads to predictive models of growth and adaptation of individual organisms and, perhaps, of species interactions and ecosystems.

Traditionally, forest genetics was built on three approaches: (1) studies of natural variation, particularly, for population and quantitative genetics, (2) micropropagation directed to plantation forestry, and (3) traditional biochemistry for studies of enzymes and metabolites, particularly for secondary metabolism. Early genetic studies of trees focused on quantitative trait variation in populations, using long-term crosses for the purpose of improving breeding material (Zobel and Talbert 1984). Genetic studies of trees focused on isozymes and population genetics (Adams et al. 1992; White et al. 2007).

The advent of DNA-based molecular markers led to the first genomic maps of forest trees (Bradshaw et al. 1994; Devey et al. 1994). Genetic analysis was greatly facilitated by the simplified segregation in the haploid megagametophyte of conifers and by the availability of polymerase chain reaction (PCR)-based molecular markers. This led to single-tree genetic maps (Tulsieram et al. 1992; Grattapaglia and Sederoff 1994; O’Malley et al. 1996) and quantitative trait mapping, e.g., to identify loci that control host resistance to fusiform rust disease in pines (Wilcox et al. 1996). Dozens of genetic maps have since been made for forest trees (Kirst et al. 2004b; http://dendrome.ucdavis.edu).

The next major advance in forest genomics came with the advent of automated DNA sequencing, which enabled high-throughput expressed sequence tag (EST) analysis in trees (Allona et al. 1998; Sterky et al. 1998, 2004; Kirst et al. 2003). A large number of ESTs are now available for forest tree species (Table 1). Microarrays developed from ESTs have been used for functional genomic studies for many of these species.

Gene transfer technology has been developed for many broadleaf species and for some conifers, particularly pine and spruce. The best-developed transformation methods are for poplars. Gene transfer experiments have shown that specific genes can have major effects on wood properties and control of flowering (Strauss et al. 1995; Chiang 2006). Many genes encoding enzymes of the monolignol biosynthetic pathway affect the chemical composition of wood (Chiang 2006).

Table 1. Some Tree Genomes Being Studied

\begin{tabular}{|c|c|c|c|c|c|c|}
\hline Species & Common name & $\begin{array}{l}\text { Genome } \\
\text { size }(\mathrm{Mbp})^{\mathrm{a}}\end{array}$ & $\begin{array}{l}\text { ESTs in } \\
\text { NCBI }^{\mathrm{b}} \\
(\text { GenBank) }\end{array}$ & $\begin{array}{l}\text { Physical } \\
\text { map (Mbp) }\end{array}$ & $\begin{array}{l}\text { Genome } \\
\text { sequence }\end{array}$ & $\begin{array}{l}\text { Properties } \\
\text { of interest }\end{array}$ \\
\hline Castanea mollissima & Chinese chestnut & 800 & none & in progress & none & disease resistance \\
\hline Cryptomeria japonica & Sugi & 10,824 & 19,605 & none & none & timber \\
\hline Eucalyptus camaldulensis & River red gum & & none & none & in progress & biomass and pulp \\
\hline Eucalyptus grandis & Flooded gum & 640 & 1,574 & in progress & in progress & biomass and pulp \\
\hline $\begin{array}{l}\text { Eucalyptus globulus } \\
\quad \text { (incl. subspecies) }\end{array}$ & Blue gum & 564 & 3,951 & none & none & biomass and pulp \\
\hline Ginkgo biloba & Ginko & 19,462 & 6,432 & none & none & $\begin{array}{l}\text { plant evolution and } \\
\text { medicine }\end{array}$ \\
\hline Gnetum gnemon & Melindjo & 3,793 & 4,323 & none & none & plant evolution \\
\hline Picea abies & Norway spruce & 18,228 & 10,217 & none & none & timber \\
\hline Picea glauca & White spruce & 19,796 & 132,624 & none & none & $\begin{array}{l}\text { biomass and } \\
\text { adaptation }\end{array}$ \\
\hline Picea sitchensis & Sitka spruce & & 139,570 & none & none & $\begin{array}{l}\text { biomass, adaptation } \\
\text { and disease } \\
\text { resistance }\end{array}$ \\
\hline Pinus elliottii & Slash pine & 22,834 & 150 & none & none & timber and pulp \\
\hline Pinus taeda & Loblolly pine & 21,658 & 329,469 & in progress & none & $\begin{array}{l}\text { biomass and } \\
\text { adaptation }\end{array}$ \\
\hline Pinus pinaster & Maritime pine & 23,863 & 27,288 & none & none & timber and pulp \\
\hline Pinus radiata & Monterey pine & 21,560 & 151 & none & none & timber and pulp \\
\hline Pinus sylvestris & Scots pine & 27,244 & 1,689 & none & none & timber and pulp \\
\hline Populus trichocarpa & Black cottonwood & 485 & 89,943 & 410 & draft sequence & model tree \\
\hline Pseudotsuga menziesii & Douglas fir & 18,669 & 18,142 & none & none & adaptation \\
\hline Quercus robur & Oak & 907 & 1,439 & none & none & $\begin{array}{l}\text { environmental } \\
\text { adaptation }\end{array}$ \\
\hline Robinia pseudoacacia & Black locust & 2,933 & 637 & none & none & $\begin{array}{l}\text { heartwood } \\
\text { formation }\end{array}$ \\
\hline
\end{tabular}

${ }^{\mathrm{a}}$ Genome sizes are only listed where published estimates exist.

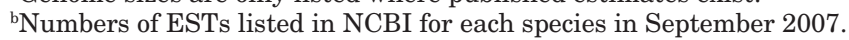


Comparative genetics has been a powerful tool for forest trees by the identification of tree candidate genes affecting related traits in the better-characterized model systems. This is possible because of the substantial sequence conservation (Kirst et al. 2003) and functional homology (Böhlenius et al. 2006) among genes of vascular plants. Genomic approaches can identify important candidate genes for molecular breeding or genetic engineering. Genes associated with variation in wood chemistry (lignin), wood density, and growth rate have been identified using such approaches (Kirst et al. 2004a; Gonzales-Martinez et al. 2006a; Li et al. 2006).

The most intensively studied forest trees are pines, spruces, poplars, and eucalypts (Table 1; Fig. 1). Within each of these genera, several species and hybrid combinations are widely planted because of their fast growth, broad adaptation to site, and superior wood properties. Many are grown as exotics in different parts of the world. Poplar has emerged as the model system for molecular studies in trees (Bradshaw et al. 2000; Taylor 2002) because of its rapid growth rate, facile propagation from cuttings, well-developed cell and tissue culture, transformability, small genome size, saturated genetic maps, and genome sequence (Tuskan et al. 2006). A chestnut genome is being characterized to advance restoration of American chestnut (Castanea dentata), a species highly valued in the 19th century that was essentially lost due to a devastating fungal blight (Steiner and Carlson 2004).

Poplar is a good model tree, but it is not widely planted compared to the pines and the eucalypts. Eucalyptus species and their hybrids are the most widely planted hardwoods. Draft sequencing of the genome of Eucalyptus camaldulensis is in progress at the Kazusa DNA Research Institute (http://www.kazusa.or.jp/e/index.html), and the Department of Energy (DOE) Joint Genome Institute expects to complete a draft of the genome sequence of Eucalyptus grandis (the rose gum) in 2010 (Myburg et al. 2008). Genomic resources developed for eucalypts include large-insert bacterial artificial chromosome (BAC) genomic libraries, ESTs, and high-resolution genetic maps (http://www.eucagen.org). Similar genomic resources are being developed for other species with the goal of genome sequencing, for example, pine, spruce, and chestnut (Table 1).

Pines and spruces are the most widely planted gymnosperms. Full-genome sequencing is a challenge in conifers due to their large genome sizes and the high proportion of repeated sequences (Kamm et al. 1996; Kossack and Kinlaw 1999; Schmidt et al. 2000; Ahuja and Neale 2005). Genome sizes of conifers range from $6500 \mathrm{Mb}$ to $\sim 37,000 \mathrm{Mb}$. The loblolly pine genome, estimated at $21,500 \mathrm{Mb}$, is about seven times larger than the human genome. A BAC library (6x) of loblolly pine has been constructed (Plomion et al. 2007), and pilot scale BAC sequencing projects are under way in the United States and Canada. With new high-throughput sequencing methods (Margulies et al. 2005; Wicker et al. 2006), draft sequences of a pine and a spruce genome are likely to be initiated soon.

\section{INFERRING FUNCTIONAL ROLES FOR GENES IN TREES}

\section{Forward Genetics}

In model plant systems such as Arabidopsis, it is possible to induce and identify mutations in most genes and to infer phenotypic and functional relationships with genes in other plants (Alonso and Ecker 2006). In most forest tree populations, the frequency of recessive mutations is high, but analysis of mutations is limited by lethality, redundancy, and difficulty in the detection of quantitative phenotypes. Due to limited selfing and long juvenility, it is difficult to make heterozygous mutations homozygous in forest trees. Some mutations can be detected in the haploid megagametophytes that surround the embryo in the seed of gymnosperms. For example, a null mutation in the monolignol biosynthetic gene Cad was discovered in megagametophytes and was subsequently mapped, sequenced, and characterized (MacKay et al. 1997; Ralph et al. 1997; Gill et al. 2003).

Forward genetics approaches such as population-wide association genetics are feasible in trees because of the high levels of genetic diversity in natural populations and breeding populations (Neale and Savolainen 2004). Experimental populations derived from interspecific hybrids have even higher levels of variation and high levels of linkage disequilibrium (Grattapaglia et al. 1996).

Another forward genetics approach that has been successful in trees is activation tagging (Busov et al. 2003), i.e., using random transgenic insertions of strong enhancers to create dominant hypermorphic phenotypes. When an enhancer is inserted near the transcriptional start site of a gene, ectopic expression of the gene may give rise to an unusual phenotype (Fig. 2). Activation-tagged trees can be screened in the field, and altered phenotypes can be detected by inspection or aerial photography. In hybrid poplar, dominant variants occurred at a frequency of $>1 \%$ and included a dwarf caused by overexpression of GA 2-oxidase, the major gibberellin catabolic enzyme (Busov et al. 2003).

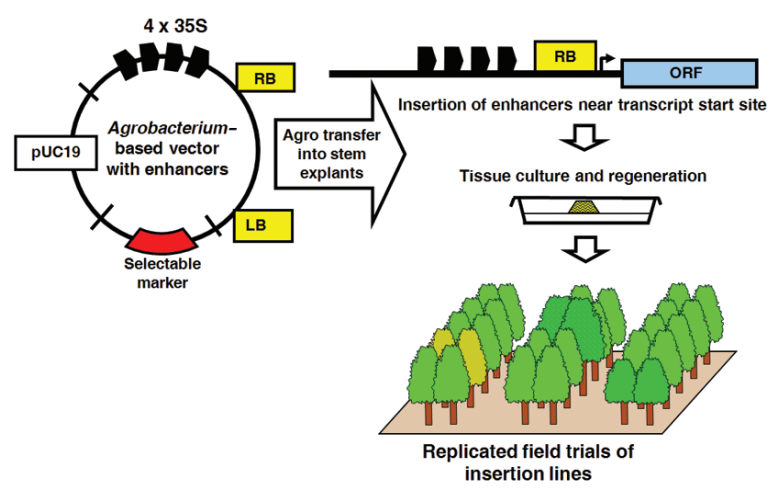

Figure 2. Activation tagging in trees. Explants of leaves or stems are cocultivated with Agrobacterium containing a pUC19-based vector carrying multiple (4x) (cauliflower mosaic virus) CaMV $35 \mathrm{~S}$ enhancer sequences. Ectopic activation of genes is detected in replicated field trials showing altered growth and developmental traits in some insertion lines. 


\section{Reverse Genetics}

For more than a decade, where candidate genes have been identified, specific transgene expression has been modified in forest trees using antisense or cosuppression (Hu et al. 1999; Li et al. 2003). More recently, suppression by RNA interference (RNAi) (Wang and Waterhouse 2002) has been used in forest trees to perform functional tests. RNAi suppression has been used to test for stability of transgene suppression in trees in the field over time (Meilan et al. 2002; Li 2006). RNAi was used in grey poplar (Populus canescens) to suppress isoprene synthase and demonstrate that isoprene protects leaves from thermal and oxidative stress (Behnke et al. 2007). Coleman et al. (2008a) used RNAi suppression of $p$-coumaroyl-CoA $3^{\prime}$ hydrolase $(\mathrm{C} 3 \mathrm{H})$ in hybrid poplar to verify the role of $\mathrm{C} 3 \mathrm{H}$ in lignin biosynthesis. The perturbation of lignification reduced tree growth and compromised vascular integrity (Coleman et al. 2008b).

\section{A Novel Method to Test Candidate Genes in Wood Formation: Somatic Sector Analysis in Developing Stem Tissues}

The lateral secondary meristem of trees is abundant and accessible and has been used to test gene function by direct transformation of cambial cells in planta (Van Beveren et al. 2006). A segment of bark is carefully removed to provide access to cambial cells that are then inoculated with Agrobacterium containing the GUS marker and a candidate gene. The bark is replaced and cambial growth resumes. Subsequently, stably transformed cambial initials differentiate, giving rise to transformed xylem and/or phloem sectors identified by GUS staining. In this way, the role of a $\beta$-tubulin gene (EgrTUB1) in microfibril angle (MFA) formation was demonstrated in Eucalyptus (Spokevicius et al. 2007). The transformed wood segments were macerated, and MFA was determined microscopically from the angle of the pit apertures in the secondary cell walls relative to the long axis of the fibers. MFA is a function of the orientation of cellulose microfibrils in the secondary walls of wood fiber cells and is a widely used indicator of the strength and dimensional stability of wood.

\section{Which Tree Genomes Are Being Studied?}

Many of the traits studied in forest trees are quantitative and are affected by multiple genes of varying degrees of effect. The genetic dissection of complex traits into defined components has been advanced greatly by the development of genetic mapping in trees. The first step in the analysis of the genetic basis of complex traits has been the localization of regions of the genome, quantitative trait loci (QTLs) that harbor factors with significant effects on the phenotype. The second step is the identification of one or more specific genes or regulatory sequences in each QTL interval responsible for the effect. Many kinds of genomic data can be analyzed as quantitative molecular phenotypes (Brem et al. 2002; Schadt et al. 2003). Transcript abundance, protein abundance, enzyme activity, and metabolite concentrations vary quantitatively in genetically diverse individuals or populations and may be regulated by alleles in one or more genes.

QTL mapping was initially considered likely to fail in forest trees, due to the complexity of growth and adaptation associated with long lifetimes (Strauss et al. 1992). However, tree growth (Bradshaw and Stettler 1995; Grattapaglia et al. 1996, 2009; Plomion et al. 1996; Verhaegen et al. 1997; Wu 1998; Kaya et al. 1999) and wood properties (Grattapaglia et al. 1996; Sewell et al. 2000, 2002; Ukrainetz et al. 2007) have been successfully studied using QTL mapping approaches. A great many quantitative traits in trees appear to be oligogenic with substantial proportions of the phenotypic variance attributable to a few genetic loci (Table 2). QTL mapping also provides a way to integrate various forms of genomic data to make associations of alleles and/or transcripts, with other quantitative traits or phenotypes, provided there is sufficient statistical power to validate such relationships (Beavis 1998; Yvert et al. 2003; Kirst et al. 2004b).

Growth rate has been the single most important trait in tree breeding and plantation forestry. Multiple QTLs for growth have been identified within species of Populus, Eucalyptus, and Pinus (Table 2) (Grattapaglia et al. 2009). Genetic differences are more readily detected in interspecific hybrids. In $\mathrm{F}_{1}$ progeny, it is possible to investigate variation within each pure-species parent, whereas an $\mathrm{F}_{2}$ cross provides detection of interspecific polymorphisms segregating in the $F_{1}$ parent. Maturation may induce a progressive shift in the genetic control of height growth, providing an explanation for the low juvenile/ mature correlation for height growth in pines.

Eucalyptus is grown widely by vegetative propagation leading to deployment of specific clones for high-quality pulp properties. QTL analysis was performed in an $E$. grandis $\mathrm{X}$ urophylla $\mathrm{F}_{1}$ hybrid progeny set for traits affecting vegetative propagation (Grattapaglia et al. 1995). QTLs were detected for rooting ability, stump sprouting, and shoot fresh weight. Similarly, genetic dissection of vegetative propagation traits was performed for E. tereticornis and E. globulus (Marques et al. 1999).

The genetic architecture of chemical and physical properties of wood also shows oligogenic structure. In an E. grandis study (Grattapaglia et al. 1996), QTLs for wood-specific gravity were identified, and in loblolly pine, QTLs were identified for MFA and wood-specific gravity (Sewell et al. 2000). QTLs for chemical properties of wood have been described in Eucalyptus (Kirst et al. 2004a) and in conifers (Sewell et al. 2002; Ukrainetz et al. 2007). QTLs have been identified for lignin content and composition and hemicellulose composition.

It had been assumed for many years that host resistance to disease in trees should be controlled by many genes of small effect because of the long lifetime of the host and the far shorter generation time of the fungal pathogens. White pine blister rust resistance in sugar pine, controlled by a single locus (Kinloch et al. 1970: Devey et al. 1995), had been viewed as an exception. The resistance phenotype of seedlings could be genetically mapped using the haploid maternal genetics of the megagametophytes (Devey et al. 1995). 
Table 2. Diversity of Traits for Which QTLs Have Been Mapped in Forest Tree Genomes (Some Examples)

\begin{tabular}{|c|c|c|c|c|c|}
\hline Species & $\begin{array}{l}\text { Type of cross and } \\
\text { size of population }^{\mathrm{a}}\end{array}$ & Trait & $\begin{array}{l}\text { Number } \\
\text { of QTLs }\end{array}$ & $\begin{array}{l}\text { Proportion } \\
\text { phenotypic } \\
\text { variance } \\
\text { explained }^{c}\end{array}$ & Reference \\
\hline $\begin{array}{l}\text { Populus trichocarpa } \mathrm{X} \\
\text { P. deltoides }\end{array}$ & interspecific $\mathrm{F}_{2}(n=55)$ & $\begin{array}{l}\text { stem volume (age } 2 \text { yr) } \\
\text { spring bud flush }\end{array}$ & $\begin{array}{l}2 \\
5\end{array}$ & $\begin{array}{l}44.7 \% \\
84.7 \%\end{array}$ & $\begin{array}{l}1 \\
1\end{array}$ \\
\hline Eucalyptus grandis & half $\operatorname{sib}(n=300)$ & $\begin{array}{l}\text { volume growth } \\
\text { wood-specific gravity }\end{array}$ & $\begin{array}{l}3 \\
5\end{array}$ & $\begin{array}{l}13.7 \% \\
25.7 \%\end{array}$ & $\begin{array}{l}2 \\
2\end{array}$ \\
\hline $\begin{array}{l}\text { Eucalyptus urophylla } \mathrm{x} \\
\text { E. grandis }\end{array}$ & interspecific $\mathrm{F}_{1}(n=200)$ & $\begin{array}{l}\text { wood density at } 38 \mathrm{mo} \\
\text { vigor at } 38 \text { mo } \\
\text { height:diameter ratio at } 38 \mathrm{mo}\end{array}$ & $\begin{array}{l}4 \\
6 \\
4\end{array}$ & $\begin{array}{l}26.4 \% \\
39.8 \% \\
31.2 \%\end{array}$ & $\begin{array}{l}3 \\
3 \\
3\end{array}$ \\
\hline Pinus taeda & full $\mathrm{sib}(n=172)$ & $\begin{array}{l}\text { percentage latewood } \\
\text { microfibril angle } \\
\text { wood-specific gravity }\end{array}$ & $\begin{array}{l}5 \\
5 \\
9\end{array}$ & $\begin{array}{l}28.6 \%^{\mathrm{d}} \\
44.8 \%^{\mathrm{d}} \\
56.0 \%{ }^{\mathrm{d}}\end{array}$ & $\begin{array}{l}4 \\
4 \\
4\end{array}$ \\
\hline Pinus pinaster & full sib $(n=202)$ & $\begin{array}{l}\text { water use efficiency }\left(\delta^{13} \mathrm{C}\right) \\
\text { diameter growth (ring width) }\end{array}$ & $\begin{array}{l}4 \\
2\end{array}$ & $\begin{array}{l}51.4 \% \\
42.9 \%\end{array}$ & $\begin{array}{l}5 \\
5\end{array}$ \\
\hline Pinus sylvestris & full $\operatorname{sib}(n=94)$ & height, frost hardiness & 12 & $9 \%-23 \%$ & 6 \\
\hline Pinus taeda & full $\operatorname{sib}(n=172)$ & $\begin{array}{l}\text { PLS of cell wall chemistry (e.g., } \\
\alpha \text {-cellulose, galactan, lignin) }\end{array}$ & 8 & $52.7 \%$ & 7 \\
\hline $\begin{array}{l}\text { Populus trichocarpa } \times \\
\text { P. deltoides }\end{array}$ & interspecific $\mathrm{F}_{2}(n=167)$ & response to drought (Abscission) & 5 & $43.0 \%$ & 8 \\
\hline $\begin{array}{l}\text { Populus deltoides } \mathrm{X} \\
\text { P. nigra and P. deltoides } \\
\times \text { P. trichocarpa }\end{array}$ & $\begin{array}{l}\text { interspecific } \mathrm{F}_{1}(n=152 \\
\quad \text { and } n=202)\end{array}$ & $\begin{array}{l}\text { metabolite concentration } \\
\text { (15 flavonoid compounds) }\end{array}$ & 4 & $24 \%-44 \%$ & 9 \\
\hline Quercus robur & full $\operatorname{sib}(n=120)$ & $\begin{array}{l}\text { water logging tolerance traits } \\
\text { (e.g., hypertrophied lenticels, } \\
\text { leaf epinasty) }\end{array}$ & 5 & $56.0 \%{ }^{\mathrm{d}}$ & 10 \\
\hline $\begin{array}{l}\text { Populus trichocarpa } \times \\
\text { P. deltoides }\end{array}$ & interspecific $\mathrm{F}_{2}(n=285)$ & $\begin{array}{l}\text { stem height under elevated } \mathrm{CO}_{2} \\
\text { stem diameter under elevated } \mathrm{CO}_{2}\end{array}$ & $\begin{array}{l}2 \\
4\end{array}$ & $\begin{array}{l}12.2 \%^{\mathrm{d}} \\
18.1 \%^{\mathrm{d}}\end{array}$ & $\begin{array}{l}11 \\
11\end{array}$ \\
\hline Eucalyptus nitens & full $\mathrm{sib}(n=296)$ & $\begin{array}{l}\text { foliar terpene ( } \alpha \text {-pinene) } \\
\text { foliar terpene (trans-pinocarveol) }\end{array}$ & $\begin{array}{l}3 \\
4\end{array}$ & $\begin{array}{l}33.3 \%^{\mathrm{d}} \\
30.6 \%^{\mathrm{d}}\end{array}$ & $\begin{array}{l}12 \\
12\end{array}$ \\
\hline Eucalyptus globulus & full $\operatorname{sib}(n=112)$ & $\begin{array}{l}\text { leaf damage (Mycosphaerella } \\
\text { leaf disease) }\end{array}$ & 2 & $52.0 \%$ & 13 \\
\hline
\end{tabular}

${ }^{a}$ Half-sib families were typically from two-generation pedigrees (seed parent and progeny, grandparents unknown), whereas full-sib families were typically from three-generation pedigrees (at least one grandparent known).

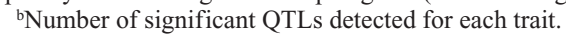

'Total proportion of the phenotypic variance explained by the QTLs.

${ }^{\mathrm{d} S u m}$ of the phenotypic variance explained by individual QTLs is given where multipoint estimates were not reported. These totals may be inflated relative to multipoint estimates of the joint effects of the same QTLs.

'PLS (Projection to latent structures) was used to identify shared variance components of several cell wall chemistry traits.

References: (1) Bradshaw and Stettler 1995; (2) Grattapaglia et al. 1996; (3) Verhaegen et al. 1997; (4) Sewell et al. 2000; (5) Brendel et al. 2002; (6) Lerceteau et al. 2000; (7) Sewell et al. 2002; (8) Street et al. 2006; (9) Morreel et al. 2006; (10) Parelle et al. 2007; (11) Rae et al. 2007; (12) Henery et al. 2007; (13) Freeman et al. 2008.

Host resistance to fusiform rust disease in loblolly pine, long thought to be a complex quantitative trait, was shown to be a simple gene-for-gene pathosystem once genome mapping was applied (Wilcox et al. 1996). Similarly, in poplar, host resistance to Melamspora medusae leaf rust was mapped to a single locus in a hybrid poplar $\mathrm{F}_{2}$ pedigree (Newcombe et al. 1996). The severity of rust in the field and in growth-room experiments was associated with Mmd1, a single factor with a major role in resistance. More recently, two QTLs were found to explain 52\% of the phenotypic variation in leaf damage of E. globulus, by the fungal pathogen Mycosphaerella cryptica (Freeman et al. 2008). Therefore, the genetic basis of host disease resistance in forest trees appears to be similar to that of annual crops.

Even when genome sequence is available, as it is for poplar, QTL regions often include hundreds of genes, and the identification of a specific candidate is not obvious. Associations can be made, however, using functional data, such as transcript abundance in combination with
QTL data, or from direct allele-trait associations in large populations in high linkage equilibrium.

\section{Transcriptomics}

Microarrays have been used to study transcriptome changes in trees during adaptation to biotic and abiotic stress, development, wood formation, maturation, and dormancy. Even relatively small numbers of ESTs in libraries from pines, spruces, eucalypts, and other species have permitted a broad scale of gene expression studies defining specificity and coordinated control. Microarrays have also been used in combination with genetic markers to map the controlling factors that regulate variation in expression of specific genes, called expression QTLs (eQTLs) (Kirst et al. 2004a, 2005).

Adaptive stress responses. Expression profiles of loblolly pine seedlings subjected to drought reflected 
photosynthetic acclimation to mild stress and photosynthetic failure during severe stress (Watkinson et al. 2003). Distinctive responses to acclimation were found for transcripts encoding heat shock proteins (e.g., HSP70 and HSP90), late embryo-abundant proteins (e.g., LEA g3), as well as enzymes of the aromatic acid and flavonoid biosynthetic pathways. Many of the responses have clear functional relationships to drought.

The response of Scots pine (Pinus sylvestris) root tissue to invasion by Heterobasidium annosum, the root and butt rot pathogen of forest trees, has been investigated using transcript profiling (Adomas et al. 2007). In general, the total number of expressed genes decreases over time of infection, but genes were up-regulated for the phenylpropanoid pathway (shikimate, lignin, and flavonoid pathways) and for oxidases (peroxidases and laccases). In a related study (Adomas et al. 2008), Scots pine transcript abundances were compared after infection with fungi of different trophic strategies, the saprotrophic fungus Trichoderma aurioviride, the pathogen Heterobasidium annosum, and the mutualistic ectomycorrhizal symbiont Laccaria bicolor. The diverse fungi elicited different transcriptional responses. The results of challenge by L. bicolor indicate substantial similarities among infection by ectomycorrhiza in angiosperms, with some differences in timing and regulation (Heller et al. 2008). The similarity of expression profiles to the responses known in agricultural crops suggests that angiosperms and gymnosperms may have similar responses to invasive pathogens.

Barakat et al. (2009) used high-throughput sequencing to compare transcripts of susceptible American chestnut (Castanea dentata) and resistant Chinese chestnut (Castanea mollissima) induced in response to chestnut blight (Cryphonectria parasitica) infection. A large number of genes associated with resistance to stresses were expressed in canker tissues, some differentially expressed in canker tissues of the two species.

cDNA microarrays were also used to study genomescale changes in transcript abundance in hybrid poplar leaves following herbivory by forest tent caterpillars (Ralph et al. 2006a). The up-regulated genes included many involved in plant defense (e.g., endochitinases), octadecanoid and ethylene signaling (e.g., lipoxygenase), secondary metabolism, and transcriptional regulation. Similarly, large-scale changes in the transcriptome were observed in Sitka spruce (Picea sitchensis) following either budworm or weevil attack (Ralph et al. 2006b).

Transcript changes in development. Variation in transcript abundance was studied during somatic embryogenesis of Norway spruce (Picea abies) to investigate early differentiation in gymnosperms (van Zyl et al. 2002; Stasolla et al. 2004). Early phases of normal embryo development are characterized by a precise pattern of induction, repression, followed by induction (up, down, and up again) as cells differentiate from proembryos to early embryos (repression), and then to late embryos (induction).

Transcriptome changes during adventitious root development (induced by an auxin pulse) in lodgepole pine ( $P$. contorta) were monitored during initiation, meristem for- mation, and root elongation (Brinker et al. 2004). During initiation, transcript abundance reflected cell wall weakening and cell replication. During root initiation, a PINHEAD/ZWILLE-like protein (with a potential role in meristem formation) was up-regulated, whereas auxin related genes were down-regulated. During meristem formation and root differentiation, transcript changes indicated that the roots had become functional in water transport and auxin transport. Expression patterns therefore provided information on general physiological responses and specific genes that may regulate those processes.

Wood formation. Microarrays have been used to investigate the variation in transcript abundance associated with wood formation (Hertzberg et al. 2001; Yang et al. 2003; Geisler-Lee et al. 2006). Wood-forming tissue has a complex, highly regulated transcriptome, with abundant expression of genes dedicated to secondary cell wall biosynthesis (Hertzberg et al. 2001; Kirst et al. 2003, 2004a; Yang et al. 2003; Paux et al. 2005; Lu et al. 2005; Geisler-Lee et al. 2006). A microarray study in Eucalyptus suggested a negative correlation of tree growth and lignification at the transcript level (Kirst et al. 2004a). Transcript abundance of lignin biosynthetic genes was highest in slow-growing trees, along with increased lignin content and abundance of syringyl lignin subunits. The most elegant use of microarray technology combined transcriptome analysis with tangential cryosectioning of the developmental gradient of differentiating xylem in poplar (Hertzberg et al. 2001) to identify stage-specific gene expression patterns. Transcripts for biosynthetic enzymes of lignin and cellulose as well as potential regulators of wood formation were found to be under stage-specific transcriptional control.

An analysis of homology and tissue specificity of transcripts for carbohydrate-active enzymes (CAZymes) in poplar and Arabidopsis (Geisler-Lee et al. 2006) compared glycosyl transferases, glycoside hydrolases, carbohydrate esterases, polysaccaridelyases, and expansins in both species. Populus has 1600 CAZyme genes compared to $\sim 1000$ for Arabidopsis. This difference may be the result of a recent genome-wide duplication event in the poplar genome (Tuskan et al. 2006) and greater emphasis on carbohydrate biosynthesis in woody tissues of poplar. Woody tissues have abundant CAZyme transcripts related to cell wall formation but low levels associated with starch formation.

Variation in gene expression has been studied in pines and poplars during growth seasons and over winter dormancy. In European aspen (P. tremula), seasonal growth and cambial dormancy involve extensive remodeling of the transcriptome (Schrader et al. 2004). The complexity of transcripts is greatly reduced in the dormant state; however, a minimal level of transcripts for some cell cycle regulators is maintained. Transcript abundance for starch enzymes increases during dormancy. Less-extensive studies in pine showed changes in abundance of transcripts for genes of cell wall biosynthesis associated with earlywood and latewood (Egertsdotter et al. 2004; Yang and Loopstra 2005).

The trunk wood of trees is differentiated into sapwood (involved in vertical transport) and heartwood, which is 
rich in chemical extractives, composed of waxes, fats, and resins. RNA obtained from the sapwood/heartwood transition zone shows transcript profiles that are more abundant for genes in flavonoid biosynthesis and many genes of unknown function (Yang et al. 2003).

Integration of quantitative and molecular genomics. Mapping QTLs provides valuable information regarding the genetic structure of complex traits and identifies genomic regions that contain genes with polymorphisms affecting traits of interest in a particular cross. This kind of information has led to the identification of positional candidate genes underlying quantitative traits in plants (Morgante and Salamini 2003); however, few genes have been identified in this way. Association of genes and QTLs requires high-resolution genetic maps, identification of genes by sequence and location, and verification by direct gene transfer. Such experiments are difficult and slow even in the most tractable forest tree species. Attempts to clone a disease resistance gene from Populus are hindered by low recombination around the resistance locus (Stirling et al. 2001). The large amount of DNA per recombination unit in conifer genomes (e.g., $12 \mathrm{Mb} / \mathrm{cM}$ in pines) makes the identification of genes by positional cloning appear to be infeasible. However, the recombination rate per chromosome in conifers is similar to that in Arabidopsis, despite a difference in genome DNA content of nearly two orders of magnitude. The density and spacing of genes per recombination unit will ultimately be a critical factor determining the success of map-based cloning. Information on gene spacing and crossover distribution has not yet been obtained for any gymnosperm, although exploratory BAC sequencing is under way for spruce and pine.

Association studies in tree populations. In many organisms, including humans, association genetics has become an established approach to detect genetic variants that may affect phenotypic variation. Large populations are screened for associations of specific markers and phenotypes. Single-nucleotide polymorphisms (SNPs) are abundant in plant genomes and have been used to find associations (Rafalski 2002; Gupta et al. 2005; Buckler et al. 2009).

Associating genes and traits in trees is challenging because of the high levels of genetic diversity, large genomes, substantial effects of environment on phenotypes, and the life history of trees (Table 3) (Neale and Savolainen 2004). Only a few specific alleles in an entire genome may be expected to have detectable quantitative effects for any given phenotype. Association genetics has been applied to wood property traits (Thumma et al. 2005; GonzalezMartinez et al. 2006a) and the drought stress-response (Gonzalez-Martinez et al. 2006b). In loblolly pine, a study of 58 SNPs in 20 wood and drought-related candidate genes found association of allelic variation in $\alpha$-tubulin with earlywood microfibril angle (Gonzalez-Martinez et al. 2006a). Association was also found for SNPs in two genes in the lignin biosynthetic pathway. Cinnamyl alcohol dehydrogenase (CAD) alleles were associated with earlywood-specific gravity, and specific alleles of the 4-coumarate CoA-ligase $(4 C L)$ gene were associated with percentage of latewood. In Eucalyptus, allelic variants of cinnamoyl CoA reductase (CCR) were associated with variation in microfibril angle (Thumma et al. 2005). Detection of gene effects at the population level in trees therefore appears to be feasible, but much larger numbers of genes and alleles need to be evaluated.

Association genetics has strengths and limitations. The power of the method depends on the size of the experimental population, heritability of the trait, number and effects of contributing genes, and allelic frequencies for these genes. Also critical for association genetics is the amount and distribution of linkage disequilibrium (LD), which determines the number of markers and the experimental approach (genome-wide scans vs. gene-based assays) used to find marker-trait associations (Gratta-paglia et al. 2009). LD decays rapidly in pines with average $r^{2}$ values of

Table 3. Genes and Markers Identified in Association with Quantitative Traits in Forest Tree Species

\begin{tabular}{|c|c|c|c|c|c|c|}
\hline $\begin{array}{l}\text { Gene/allele } \\
\text { or marker }\end{array}$ & $\begin{array}{l}\text { Location } \\
\text { (genic/intergenic) }\end{array}$ & Trait & Species & $\begin{array}{l}\text { Detection } \\
\text { approach }\end{array}$ & Population & Reference \\
\hline cad/cad-n1 & genic (exon) & wood density & $\begin{array}{l}\text { loblolly pine } \\
\text { (Pinus taeda) }\end{array}$ & n.a. & n.a. & Wu et al. (1999) \\
\hline $\begin{array}{l}\text { RCI2/marker } \\
\text { unknown }\end{array}$ & unknown & wood density & $\begin{array}{l}\text { E. grandis and } \\
\text { E. globulus }\end{array}$ & $\begin{array}{l}\text { QTL/genetical } \\
\text { genomics }\end{array}$ & $\begin{array}{l}\text { pseudo-backcross } \\
\text { hybrid population }\end{array}$ & $\begin{array}{l}\text { M. Kirst et al. } \\
\text { (unpubl.) }\end{array}$ \\
\hline $\begin{array}{l}c c r / \mathrm{SNP} 20 \\
\text { and SNP21 }\end{array}$ & genic (intron) & $\begin{array}{l}\text { microfibril } \\
\text { angle }\end{array}$ & E. globulus & LD mappin & $\begin{array}{l}\text { unrelated gentoypes } \\
\quad(n=290)\end{array}$ & Thumma et al. \\
\hline sams-2/M44 & genic (intron) & $\begin{array}{l}\text { earlywood- } \\
\text { specific } \\
\text { gravity }\end{array}$ & $\begin{array}{l}\text { loblolly pine } \\
\quad \text { (Pinus taeda) }\end{array}$ & LD mapping & $\begin{array}{l}\text { unrelated gentoypes } \\
\quad(n=435)\end{array}$ & $\begin{array}{l}\text { Gonzales-Martinez } \\
\text { et al. (2006a) }\end{array}$ \\
\hline $\mathrm{cad} / \mathrm{M} 28$ & genic (exon) & $\begin{array}{l}\text { earlywood- } \\
\text { specific } \\
\text { gravity }\end{array}$ & $\begin{array}{l}\text { loblolly pine } \\
\quad \text { (Pinus taeda) }\end{array}$ & LD mapping & $\begin{array}{l}\text { unrelated gentoypes } \\
\quad(n=435)\end{array}$ & $\begin{array}{l}\text { Gonzales-Martinez } \\
\text { et al. (2006a) }\end{array}$ \\
\hline lp3-1/Q5 & genic (UTR) & $\begin{array}{l}\text { percentage } \\
\text { of latewood }\end{array}$ & $\begin{array}{l}\text { loblolly pine } \\
\text { (Pinus taeda) }\end{array}$ & LD mapping & $\begin{array}{l}\text { unrelated gentoypes } \\
\quad(n=435)\end{array}$ & $\begin{array}{l}\text { Gonzales-Martinez } \\
\text { et al. }(2006 \mathrm{a})\end{array}$ \\
\hline$\alpha$-tubulin/M10 & genic (intron) & $\begin{array}{l}\text { earlywood } \\
\text { microfibril } \\
\text { angle }\end{array}$ & $\begin{array}{l}\text { loblolly pine } \\
\text { (Pinus taeda) }\end{array}$ & LD mapping & $\begin{array}{l}\text { unrelated gentoypes } \\
\quad(n=422)\end{array}$ & $\begin{array}{l}\text { Gonzales-Martinez } \\
\text { et al. (2006a) }\end{array}$ \\
\hline
\end{tabular}

Abbreviations: (cad) Cinnamyl alcohol dehydrogenase; (ccr-1), cinnamoyl CoA reductase 1; (sams-2) S-adenosylmethioninesynthetase 2; (lp3-1) water-stress-inducible protein 1; (n.a.) not applicable. 
0.2 for sites within $2 \mathrm{~kb}$ of each other (Brown et al. 2004). Similar rates of decay have been reported in Eucalyptus (Thumma et al. 2005) and Populus (Ingvarsson 2005). At such low levels of LD, there should be little correlation between adjacent genes, and an association of a gene and a trait implies a direct effect. However, to achieve such resolution, multiple, well-spaced markers are needed, preferably for all genes. New ultra-high-throughput DNA sequencing technologies (Wicker et al. 2006) enable the discovery of many SNPs in large numbers of tree genes, paving the way for genome-wide gene-based association genetics in trees. A recent study in Eucalyptus (Novaes et al. 2008) shows that very large numbers of informative SNPs can be readily obtained using this technology.

Genetical genomics in forest trees. Quantitative genetic analysis of transcript abundance and trait variation in segregating populations can identify functional associations of genes and traits, providing a powerful complement to association genetic studies. This approach, called genetical genomics (Jansen and Nap 2001), is based on the expectation that transcript level variation should be correlated with trait variation where allelic polymorphisms affect gene expression. Many genes show significant variation in transcript abundance associated with segregating genotypes, which can be considered quantitative traits and therefore be mapped as eQTLs. Studies in yeast, Drosophila, mice, maize, humans, and forest trees (Brem et al. 2002; Wayne and McIntyre 2002; Schadt et al. 2003; Yvert et al. 2003; Kirst et al. 2004a; Bystrykh et al. 2005; Hubner et al. 2005) revealed large numbers of specific genes with heritable variation in transcript abundance. Transcript abundance is measured in mapping pedigrees by microarray analysis, and gene-trait associations are inferred by the colocation of the resulting eQTLs and trait QTLs.

eQTLs provide information about gene regulation in two ways. If a site regulating transcript variation is coincident with the location of the gene encoding the transcript, then variation of transcript abundance is inferred to be $c$ is regulated, (i.e., the controlling element is within or very near to the gene itself). If the eQTL is located elsewhere in the genome, gene expression is inferred to be regulated in trans, by a polymorphism in another molecule, presumably RNA or protein. A trans-acting eQTL shared by several genes (giving rise to an "eQTL hot spot") may indicate polymorphism in a transcription factor that regulates many genes coordinately.

Besides transcript profiling tools, genetical genomics in trees requires large-scale determination of phenotypes such as wood chemistry, tree physiology and disease resistance. High-throughput nondestructive measurement systems of wood chemistry by near-infrared (NIR) spectroscopy (Schimleck et al. 2000; Yeh et al. 2005) have been developed that allow genetic dissection of wood properties in large populations. Gene expression arrays are now available for several tree species (Hertzberg et al. 2001; Yang et al. 2003; Ralph et al. 2006a; EUCAGEN [www.eucagen.org]; NSF-GLPEP 2007 [http://compbio.dfci.harvard.edu/cgibin/tgi/gimain.pl?gudb=pine]). The costs of phenotyping and microarray analysis for large populations and the estab- lishment of new large experimental populations may be the most serious limitations for application of genetical genomics.

We have studied a wide interspecific cross of $E$. grandis $\times$ globulus species that are planted for rapid growth $(E$. grandis) and high wood density (E. globulus) (Myburg 2001; Myburg et al. 2003, 2004). QTLs were identified for many traits, including wood density, growth rate, and wood properties (Myburg 2001; Kirst et al. 2004a). At least two chromosomal regions showed a significant correlation with lignin content (Fig. 3). A segment from the E. globulus parent on linkage group 3 (LG3) was associated with decreased lignin relative to the $E$. grandis allele, and a site on LG7 associated increased lignin and a segment from $E$. globulus. Segregating eQTLs were detected for large numbers of genes (Kirst et al. 2005). eQTLs were detected for $41 \%$ of 2304 genes represented on a microarray, of which $77 \%$ had a single eQTL. For the remaining 23\%, more than one significant eQTL was detected.

eQTL analysis has also allowed us to identify a candidate gene for wood density in this Eucalyptus hybrid population (Myburg 2001; Kirst et al. 2004a). The abundance of one gene transcript, a Eucalyptus cDNA that has homology with the RCI-2 gene of Arabidopsis (Jarillo et al. 1994), was strongly associated with wood density (Fig. 4 , left). Several other transcripts were associated with diameter growth rate and lignin properties and appeared

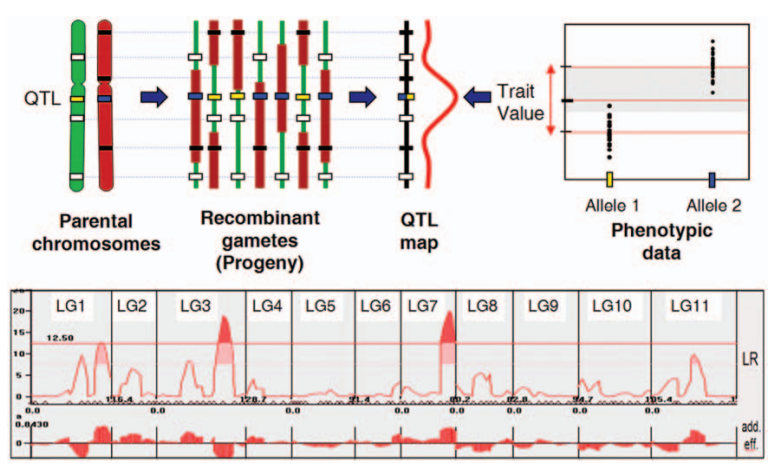

Figure 3. QTL mapping in progeny of heterozygous trees. (Top) Schematic representation of the use of dominant molecular markers to track the inheritance of parental chromosome segments in segregating progeny and associate the presence of alternative alleles with differences in trait values. The strength of the association is represented by the QTL graph (thick red line), which is a likelihood ratio (LR) test statistic for the difference in trait means of progeny with alternative marker alleles. QTL allele effects (relative to the trait mean) are indicated by red arrows. (Bottom) Example of a QTL scan for lignin content in the genome of a $F_{1}$ hybrid of $E$. grandis $\times$ globulus backcrossed to a unrelated $E$. grandis individual (i.e., trait variation in $\mathrm{F}_{2}$ pseudo-backcross progeny (Myburg 2001; Kirst et al. 2004a). Significant and suggestive composite interval mapping LR thresholds (solid and broken lines) correspond to approximate experiment-wise $a=0.05$ and $a=0.3$, respectively. The additive effect of putative QTLs is indicated below the LR plot and shows the magnitude and direction of the effect of the E. globulus allele relative to that of the $E$. grandis allele in the $\mathrm{F}_{1}$ hybrid. The 11 linkage groups are shown end to end, and positions of framework markers are indicated by triangles $(\Delta)$ along the $x$ axis. 

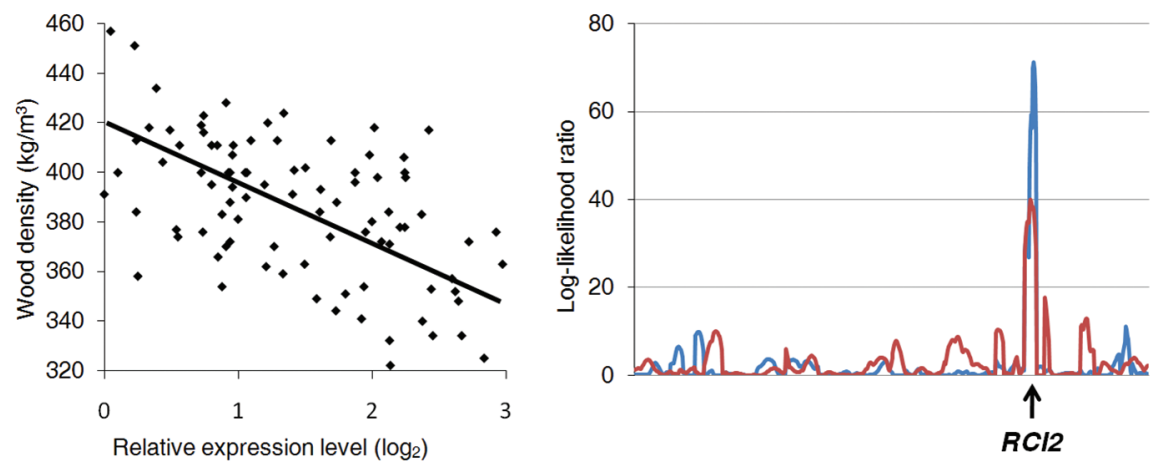

Figure 4. Association of variation in transcript abundance of the RCI-2 homolog of Eucalyptus with wood density in an E. grandis $\mathrm{X}$ globulus hybrid $\mathrm{F}_{2}$ progeny. (Left) Correlation analysis identified a significant association between $R C I-2$ relative expression level and wood density measured in the $\mathrm{F}_{2}$ population $\left(r^{2}=0.28, p<0.0001\right)$. (Right) Colocalization of the $R C I-2$ gene locus, $R C I-2 \mathrm{eQTL}$ (black line), and wood density QTL (gray line) on the hybrid parent genetic map further defined $R C I-2$ as a strong candidate for regulation of the trait variation. The arrow indicates the genetic location of $R C I-2$.

to be coordinately controlled (Kirst et al. 2004a). Among the genes most strongly and negatively associated with growth were several genes encoding enzymes for monolignol biosynthesis. The strongest correlation with growth was found for Cald5H $\left(r^{2}=0.38\right)$, known to regulate the angiosperm-specific branch of monolignol biosynthesis forming sinapyl alcohol (Chiang 2006).

The association of transcript variation and trait variation can be confirmed by evaluating the colocation of the genes, the eQTL regulating transcript level, and the QTL(s) for the trait of interest. In the case of the RCI-2 transcript, all three (the gene, eQTL, and wood density QTL) were colocalized (Fig. 4, right), suggesting that the RCI-2eQTL affects cis regulation of the gene itself. In the case of the monolignol genes (Kirst et al. 2004a), the polymorphisms affecting their transcript levels (i.e., the eQTLs) did not colocalize with the genes, but they appeared to exert coordinate control. The shared eQTLs (eQTL hot spots) may be trans-acting regulators of the lignin biosynthetic pathway.

Under appropriate conditions, eQTLs can explain a larger component of the total phenotypic variance than traditional marker-based trait QTLs. In the case of $R C I-2$, the eQTL based on transcript level variation accounted for $28 \%$ of the total phenotypic variance, whereas the marker-based QTL in the same region accounted for only $11 \%$ of the variance. Phenotypic traits are subject to additional developmental and environmental variation that affects their transcript levels. Transcript level measurements can therefore have greater power to detect genetic associations than markers alone.

It has not yet been possible to determine the nature of the eQTLs associated with lignin biosynthesis and growth in the $E$. grandis $\times$ globulus backcross pedigree in the absence of genome sequence. Preliminary genetical genomics studies in $\mathrm{F}_{2}$ hybrid progeny of $P$. trichocarpa and $P$. deltoides succeeded in identifying candidate genes that colocate with drought resistance QTLs (Street et al. 2006).

In the near future, we may expect genetical genomics and association genetics to uncover many associations of specific genes with disease resistance, insect resistance, climatic adaptation, wood properties, and carbon allocation in both hardwoods and conifers.

\section{CONCLUSIONS}

\section{Genome Content and Evolution}

Research should focus on obtaining fundamental information on gene content, gene location, and gene function in key species through comparative genomics. A pressing goal will be the ability to infer functional gene orthology across the major taxa of higher plants. Comparison of the genomes and transcriptomes of herbaceous and woody plants will help to elucidate the genetic basis of the woody growth form and perennial plant life. A major objective should be the de novo sequencing of genomes within the gymnosperms and a great many of angiosperm tree genomes to gain a detailed understanding of genome evolution in trees.

\section{Population Genomics}

Further integration of molecular and quantitative research tools will come from studies of quantitative variation in populations and, in particular, where associations can be made directly between alleles and phenotypes on a genomic scale. New methods for high-throughput phenotyping of traits and the physical and chemical properties of cells and tissues will make more associations possible. Applications may be expected in both plantations and natural populations. Comparisons of populations within and between related species will provide new insights into the evolution of many woody plant genera.

\section{Metabolomics}

The characterization of large numbers of metabolites from cells and tissues (Fiehn et al. 2000) would be of great value for forest trees to study chemical diversity and to associate metabolites with genes. Such associations 
could aid in assigning function to unknown genes, many of which may be involved in secondary metabolic pathways that may be less readily studied in model plants. Specific applications of global metabolite profiling will be particularly important for understanding interactions of insect pests and the chemical defenses of tree hosts (Henery et al. 2007).

\section{Environmental Genomics}

Environmental genomics (also called Ecogenomics) is an emerging area of tree biology (Whitham et al. 2006). The application of genomics to the breeding or engineering of a blight-resistant American chestnut (Steiner and Carlson 2004; Wheeler and Sederoff 2009) aimed at species restoration is a model for many endangered tree species where both conservation and genetic intervention may be needed. Such species include fraser fir, lodgepole pine, American beech, sugar pine, and American elm. Trees are desirable for bioremediation with the added advantage of carbon sequestration. Recently, transgenic poplar plants expressing a cytochrome P450 were shown to increase metabolism and remove halogenated hydrocarbons from hydroponic solution (Doty et al. 2007).

\section{Woody Biomass for Energy}

Large efforts in tree genomics will be directed to the improved use of woody biomass for fermentation to ethanol or for thermal conversion to electrical energy. The successful use of trees as bioenergy crops will require increased forest tree productivity and changes in wood biochemistry that will make cellulosics from wood more accessible for saccharification and fermentation. Alternatively, wood with high lignin content is a superior source of thermal energy, and efforts may also be directed to produce fast-growing high-content lignin trees. A substantial gap exists between the current information and what is needed to describe the relationship between genotype and phenotype by predictive models for important traits such as biomass production in forest trees.

\section{ACKNOWLEDGMENTS}

This work was supported in part by grants from the National Science Foundation (DBI-0605135) and the Consortium for Plant Biotechnology Research (GO12026-225).

\section{REFERENCES}

Adams WT, Strauss SH, Copes DL, Griffin AR. 1992. Population genetics of forest trees. Kluwer, Dordrecht, The Netherlands.

Adomas A, Heller G, Li G, Olson A, Chu T-M, Osborne J, Craig D, Van Zyl L, Wolfinger R, Sederoff R, et al. 2007. Transcript profiling of conifer pathosystem: Response of Pinus sylvestris root tissues to pathogen (Heterobasidion annosum) invasion. Tree Physiol 27: 1441-1458.

Adomas A, Heller G, Olson A, Osbourne J, Karlsson M, Nahalkova J, van Zyl L, Sederoff R, Stenlid J, Finlay R,
Asiegbu FO. 2008. Comparative analysis of transcript abundance in Pinus sylvestris after challenge with a saprophytic, pathogenic or mutualistic fungus. Tree Physiol 28: 885-897.

Ahuja MR, Neale DB. 2005. Evolution of genome size in conifers. Silvae Genet 54: 126-137.

Allona I, Quinn M, Shoop E, Swope K, St. Cyr S, Carlis J, Riedl J, Retzel E, Campbell MM, Sederoff RR, et al. 1998. Analysis of xylem formation in pine by cDNA sequencing. Proc Natl Acad Sci 95: 9693-9698.

Alonso JM, Ecker JR. 2006. Moving forward in reverse: Genetic technologies to enable genome-wide phenomic screens in Arabidopsis. Nat Rev Genet 7: 524-536.

Barakat A, DiLoreto DS, Zhang Y, Smith C, Baier K, Powell WA, Wheeler N, Sederoff R, Carlson JE. 2009. Comparison of the transcriptomes of American chestnut (Castanea dentata) and Chinese chestnut (Castanea mollissima) in response to the chestnut blight infection. BMC Plant Biol 9: 51 .

Beavis WD. 1998. QTL analysis: Power, precision, and accuracy. In Molecular dissection of complex traits (ed. HA Patterson), pp. 145-162. CRC, Boca Raton, FL.

Behnke K, Ehlting B, Teuber M, Bauerfeind M, Louis S, Hansch R, Polle A, Bohlmann J, Schnitzler J-P. 2007. Transgenic, nonisoprene emitting poplars don't like it hot. Plant J 51: 485-499.

Boerjan W. 2005. Biotechnology and the domestication of forest trees. Curr Opin Biotechnol 16: 159-166.

Böhle U, Hilger H, and Martin WF. 1996. Island colonization and evolution of the insular woody habit in Echium L. (Boraginaceae). Proc Natl Acad Sci 93: 11740-11745.

Böhlenius H, Huang T, Charbonnel-Campaa L, Brunner AM, Jansson S, Strauss SH, Nilsson O. 2006. Co/FT regulatory module controls timing of flowering and seasonal growth cessation in trees. Science 312: 1040-1043.

Bowe LM, Coat G, de Pamphilis C. 2000. Phylogeny of seed plants based on all three genomic compartments: Extant gymnosperms are monophyletic and Gnetales' closest relatives are conifers. Proc Natl Acad Sci 97: 4092-4097.

Bradshaw HD Jr, Stettler RF. 1995. Molecular genetics of growth and development in Populus. 4. Mapping QTLs with large effects on growth, form, and phenology traits in a forest tree. Genetics 139: 963-973.

Bradshaw HD Jr, Villar M, Watson BD, Otto KG, Stewart S, Stettler RF. 1994. Molecular genetics of growth and development in Populus. III. A genetic linkage map of a hybrid poplar composed of RFLP, STS, and RAPD markers. Theor Appl Genet 89: 167-178.

Bradshaw HD Jr, Ceulemans R, Davis J, Stettler R. 2000. Emerging model systems in plant biology: Poplar (Populus) as a model forest tree. J Plant Growth Regul 19: 306-313.

Brem RB, Yvert G, Clinton R, Kruglyak L. 2002. Genetic dissection of transcriptional regulation in budding yeast. Science 296: 752-755.

Brendel O, Pot D, Plomion C, Rozenberg P, Guehl JM. 2002. Genetic parameters and QTL analysis of $\mathrm{d}^{13} \mathrm{C}$ and ring width in maritime pine. Plant Cell Environ 25: 945-953.

Brinker M, van Zyl L, Liu W, Craig D, Sederoff R, Clapham D, von Arnold S. 2004. Microarray analyses of gene expression during adventitious root development in Pinus contorta. Plant Physiol 135: 1526-1539.

Brown GR, Gill GP, Kuntz RJ, Langley CH, Neale DB. 2004. Nucleotide diversity and linkage disequilibrium in loblolly pine. Proc Natl Acad Sci 10: 15255-15260.

Brunner AM, Busov VB, Strauss SH. 2004. Poplar genome sequence: Functional genomics in an ecologically dominant plant species. Trends Plant Sci 9: 49-56.

Buckler ES, Holland JB, Bradbury PJ, Acharya CB, Brown PJ, Browne C, Ersoz E, Flint-Garcia S, Garcia A, Glaubitz JC, et al. 2009. The genetic architecture of maize flowering time. Science 235: 714-718.

Burleigh JG, Mathews S. 2004. Phylogenetic signal in nucleotide data from seed plants: Implications for resolving the seed plant tree of life. Am J Bot 91: 1599-1613.

Busov VB, Meilan R, Pearce DW, Ma C, Rood SB, Strauss SH. 2003. Activation tagging of a dominant gibberellin catabo- 
lism gene (GA 2-oxidase) from poplar that regulates tree stature. Plant Physiol 132: 1283-1291.

Bystrykh L, Weersing E, Dontje B, Sutton S, Pletcher MT, WiltshireT, Su AI, Vellenga E, Wang J, Manly KF, et al. 2005. Uncovering regulatory pathways that affect hematopoietic stem cell function using "genetical genomics." Nat Genet 37: 225232.

Campbell MM, Brunner AM, Jones HM, Strauss SH. 2003. Forestry's fertile crescent: The application of biotechnology to forest trees. Plant Biotechnol 1: 141-154.

Chaffey N, Cholewa E, Regan S, Sundberg B. 2002. Secondary xylem development in Arabidopsis: A model for wood formation. Physiol Plant 114: 594-600.

Chaloner WG, Macdonald P. 1980. Plants invade the land. Royal Scottish Museum, Edinburgh.

Chaw SM, Parkinson CL, Cheng Y, Vincent TM, Palmer JD. 2000. Seed plant phylogeny inferred from all three plant genomes: Monophyly of extant gymnosperms and origin of Gnetales from conifers. Proc Natl Acad Sci 97: 4086-4091.

Chiang VL. 2006. Monolignol biosynthesis and genetic engineering of lignin in trees, a review. Environ Chem Lett 4: 143-146.

Coleman HD, Park J-Y, Nair R, Chapple C, Mansfield SD. 2008a. RNAi-mediated suppression of $p$-coumaroyl-CoA 3 '-hydrolase in hybrid poplar impacts lignin deposition and soluble secondary metabolism. Proc Natl Acad Sci 105: 4501- 4506.

Coleman HD, Samuels AL, Guy RD, Mansfield SD. 2008b. Perturbed lignification impacts tree growth in hybrid poplar: A function of sink strength, vascular integrity and photosynthetic assimilation. Plant Physiol 148: 1229-1237.

de la Torre JEB, Egan MG, Katari MS, Brenner ED, Stevenson DW, Coruzzi GM, DeSalle R. 2006. ESTimating plant phylogeny: Lessons from partitioning. BMC Evol Biol 6: 48.

DeVerno LL, Mosseler A. 1997. Genetic variation in red pine (Pinus resinosa) revealed by RAPD and RAPD-RFLP analysis. Can J For Res 27: 1316-1320.

Devey ME, Fiddler TA, Liu BH, Knapp SJ, Neale DB. 1994. An RFLP linkage map for loblolly pine based on a 3-generation outbred pedigree. Theor Appl Genet 88: 273-278.

Devey ME, Delfinomix A, Kinloch BB, Neale DB. 1995. Random amplified polymorphic DNA markers tightly linked to a gene for resistance to white-pine blister rust in sugar pine. Proc Natl Acad Sci 92: 2066-2070.

Doebley J, Lukens L. 1998. Transcriptional regulators and the evolution of plant form. Plant Cell 10: 1075-1082.

Doebley J, Stec A, Hubbard L. 1997. The evolution of apical dominance in maize. Nature 386: 485-488.

Dolan L, Roberts K. 1995. Secondary thickening in roots of Arabidopsis thaliana: Anatomy and cell-surface changes. New Phytol 131: 121-128.

Doty SL, James CA, Moore AL, Vaizovic A, Singleton GL, Ma C, Kahn Z, Xin G, Kang JW, Park JY, et al. 2007. Enhanced phytoremediation of volatile environmental pollutants with transgenic trees. Proc Natl Acad Sci 104: 16816-16821.

Egertsdotter U, van Zyl LM, MacKay J, Peter G, Kirst M, Clark C, Whetten R, Sederoff R. 2004. Gene expression during formation of earlywood and latewood in loblolly pine: Expression profiles of 350 genes. Plant Biol 6: 654-663.

EUCAGEN. The Eucalyptus Genome Network (http://www. eucagen.org).

FAO (Food and Agriculture Organization). 2001. Global forest resources assessment 2000: Main report. Food and Agriculture Organization (FAO) Forestry Paper 140 (Rome).

Fenning TM, Gershenzon J. 2002. Where will the wood come from? Plantation forests and the role of biotechnology. Trends Biotechnol 20: 291-296.

Fiehn O, Kopka J, Dörmann P, Altmann T, Trethewey RN, Willmitzer L. 2000. Metabolite profiling for plant functional genomics. Nat Biotechnol 18: 1157-1161.

Freeman JS, Potts BM, Vaillancourt RE. 2008. Few Mendelian genes underlie the quantitative response of a forest tree, Eucalyptus globulus, to a natural fungal epidemic. Genetics 178: 563-571.

Frewen BE, Chen THH, Howe GT, Davis J, Rohde A, Boerjan W,
Bradshaw HD Jr. 2000. Quantitative trait loci and candidate gene mapping of bud set and bud flush in Populus. Genetics 154: $837-845$

Geisler-Lee J, Geisler M, Coutinho P, Segerman B, Nishikubo N, Takahashi J, Aspenborg H, Djerbi S, Masters E, AnderssonGunner S, et al. 2006. Poplar carbohydrate-active enzymes (CAZymes). Gene identification and expression analysis. Plant Physiol 140: 946-962.

Gill GP, Brown GR, Neale DB. 2003. A sequence mutation in the cinnamyl alcohol dehydrogenase gene associated with altered lignification in loblolly pine. Plant Biotechnol 1: 253-258.

Gonzalez-Martinez SC, Wheeler NC, Ersoz E, Nelson DR, Neale DB. 2006a. Association genetics in Pinus taeda L. I. Wood property traits. Genetics 175: 399-409.

Gonzalez-Martinez SC, Ersoz E, Brown GR, Wheeler NC, Neale DB. 2006b. DNA sequence variation and selection of tag SNPs at candidate genes for drought-stress response in Pinus taeda L. Genetics 172: 1915-1926.

Grattapaglia D, Sederoff R. 1994. Genetic linkage maps of Eucalyptus grandis and Eucalyptus urophylla using a pseudotestcross mapping strategy and RAPD markers. Genetics 137: $1121-1137$.

Grattapaglia D, Bertolucci FL, Sederoff RR. 1995. Genetic mapping of QTLs controlling vegetative propagation in Eucalyptus grandis and E. urophylla using a pseudo-testcross strategy and RAPD markers. Theor Appl Genet 90: 933-947.

Grattapaglia D, Bertolucci FL, Penchel R, Sederoff RR. 1996. Genetic mapping of quantitative trait loci controlling growth and wood quality traits in Eucalyptus grandis using a maternal half-sib family and RAPD markers. Genetics 144: 1205-1214.

Grattapaglia D, Plomion C, Kirst M, Sederoff RR. 2009. Genomics of growth traits in forest trees. Curr Opin Plant Biol 12: $148-156$.

Gray KA, Zhao L, Emptage M. 2006. Bioethanol. Curr Opin Chem Biol 10: 141-146.

Groover AT. 2005. What genes make a tree a tree? Trends Plant Sci 10: 210-214.

Gupta PK, Rustgi S, Kulwal PL. 2005. Linkage disequilibrium and association studies in higher plants: Present status and future prospects. Plant Mol Biol 57: 461-485.

Hamrick JL, Godt MJW, Sherman-Broyles SL. 1992. Factors influencing levels of genetic diversity in woody plant species. New Forests 6: 95-124.

Helfgott DM, Fransisco-Ortega J, Santos-Guerra A, Jansen RK, Simpson BB. 2000. Biogeography and breeding system evolution of the woody Bencomia alliance (Rosaceae) in Macronesia based on ITS sequence data. Syst Bot 25: 82-97.

Heller G, Adomas A, Li G, Osbourne J, van Zyl L, Sederoff R, Finlay R, Stenlid J, Asiegbu F. 2008. Transcriptional analysis of Pinus sylvestris roots challenged with the ectomycorrhizal fungus Lacciaria bicolor. BMC Plant Biol 8: 19.

Henery ML, Moran GF, Wallis IR, Foley WJ. 2007. Identification of quantitative trait loci influencing foliar concentrations of terpenes and formylated phloroglucinol compounds in Eucalyptus nitens. New Phytol 176: 82-95.

Hertzberg M, Aspeborg H, Schrader J, Andersson A, Erlandsson R, Blomqvist K., Bhalero R, Uhlen M, Teeri TT, Lundeberg J, et al. 2001. A transcriptional roadmap to wood formation. Proc Natl Acad Sci 98: 14732-14737.

Hu W-J, Harding SA, Lung J, Popko JL, Ralph J, Stokke DD, Tsai C-J, Chiang VL. 1999. Repression of lignin biosynthesis promotes cellulose accumulation and growth in transgenic trees. Nat Biotechnol 17: 808-812.

Hubner N, Wallace CA, Zimdahl H, Petretto E, Schulz H, Maciver F, Mueller M, Hummel O, Monti J, Zidek V, et al. 2005. Integrated transcriptional profiling and linkage analysis for identification of genes underlying disease. Nat Genet 37: $243-$ 253.

Ingvarsson PK. 2005. Nucleotide polymorphism and linkage disequilibrium within and among natural populations of European aspen (Populus tremula L., Salicaceae). Genetics 169: 945-953. Jaenicke-Després V, Buckler ES, Smith BD, Gilbert MTP, Cooper A, Doebley J, Pääbo S. 2003. Early allelic selection in 
maize as revealed by ancient DNA. Science 302: 1206-1208. Jansen RC, Nap JP. 2001. Genetical genomics: The added value from segregation. Trends Genet 17: 388-391.

Jarillo JA, Capel J, Leyva A, Martinez-Zapater JM, Salinas J. 1994 Two related low-temperature-inducible genes of Arabidopsis encode proteins showing high homology to 14-3-3 proteins, a family of putative kinase regulators. Plant Mol Biol 25: 693-704.

Kamm A, Doudrick RL, Heslop-Harrison JS, Schmidt T. 1996. The genomic and physical organization of Ty1-copia-like sequences as a component of large genomes in Pinus elliottii var. elliottii and other gymnosperms. Proc Natl Acad Sci 93: 2708-2713.

Kaya Z, Sewell MM, Neale DB. 1999. Identification of quantitative trait loci influencing annual height- and diameter-increment growth in loblolly pine (Pinus taeda L.). Theor Appl Genet 98: 586-592.

Kinloch BB Jr, Parks GK, Fowler CW. 1970. White pine blister rust: Simply inherited resistance in sugar pine. Science 167: 193-195.

Kirst M, Johnson A, Baucom C, Ulrich E, Hubbard C, Staggs R, Paule C, Retzel E, Whetten R, Sederoff R. 2003. Apparent homology of expressed genes from wood-forming tissues of loblolly pine (Pinus taeda L.) with Arabidopsis thaliana. Proc Natl Acad Sci 100: 7383-7388.

Kirst M, Myburg AA, Kirst ME, Scott J, Sederoff RR. 2004a. Coordinated genetic regulation of growth and lignin content revealed by QTL analysis of cDNA microarray data in an interspecific cross of Eucalyptus. Plant Physiol 135: 2368-2378.

Kirst M, Myburg A, Sederoff R. 2004b. Genetic mapping in forest trees: Markers linkage analysis and genomics. Genet Eng 26: $106-141$

Kirst M, Basten CJ, Myburg AA, Zeng ZB, Sederoff RR. 2005. Genetic architecture of transcript-level variation in differentiating xylem of a eucalyptus hybrid. Genetics 169: 2295-2303.

Ko JH, Prassinos C, Han KH. 2006. Developmental and seasonal expression of PtaHB1, a Populus gene encoding a class III HD-Zip protein, is closely associated with secondary growth and inversely correlated with the level of microRNA (miR166). New Phytol 169: 469-478.

Koch GW, Sillett SC, Jennings GM, Davis SD. 2004. The limits to tree height. Nature 428: 851-854.

Kossack D, Kinlaw C. 1999. IFG, a gypsy-like retrotransposon in Pinus (Pinaceae) has an extensive history in pines. Plant Mol Biol 39: 417-426.

Larson PR. 1994. The vascular cambium: Development and structure. Springer, Berlin.

Lerceteau E, Plomion C, Andersson B. 2000. AFLP mapping and detection of quantitative trait loci (QTLs) for economically important traits in Pinus sylvestris: A preliminary study. Mol Breed 6: 451-458.

Lev-Yadun S. 1994. Induction of sclereid differentiation in the pith of Arabidopsis thaliana (L.) Heynh. J Exp Bot 45: 1845 1849.

Lev-Yadun S, Abbo S, Doebley J. 2002. Wheat, rye, and barley on the cob? Nat Biotechnol 20: 337-338.

Li J. 2006. "Stability of reporter gene expression and RNAi in transgenic poplars over multiple years in the field under vegetative propogation." PhD thesis, Oregon State University, Portland.

Li L, Zhou Y, Cheng XF, Sun J, Marita J, Ralph J, Chiang VL. 2003. Combinatorial genetic reduction of lignin quantity and augmentation of lignin syringyl constituents in trees through multigene co-transformation. Proc Natl Acad Sci 100: 4939-4944.

Li L, Lu S, Chiang V. 2006. A genomic and molecular view of wood formation. Crit Rev Plant Sci 25: 215-233.

Lu S, Sun Y-H, Shi R, Clark C, Li L, Chiang VL. 2005. Novel and mechanical stress-responsive microRNAs in Populus trichocarpa that are absent from Arabidopsis. Plant Cell 17: 2186-2203.

MacKay J, O'Malley DM, Presnell T, Booker FL, Campbell MM, Whetten RW, Sederoff RR. 1997. Inheritance, gene expression, and lignin characterization in a mutant pine deficient in cinnamyl alcohol dehydrogenase. Proc Natl Acad Sci 94: $8255-8260$.
Magallón S, Sanderson MJ. 2002. Relationships among seed plants according to highly conserved genes: Sorting conflicting phylogenetic signals among ancient lineages. Am J Bot 89: 1991-2006.

Margulies M, Egholm M, Altman WE, Attiya S, Bader JS, Bemben LA, Berka J, Braverman MS, Chen YJ, Chen Z, et al. 2005. Genome sequencing in microfabricated high-density picolitre reactors. Nature 437: 376-380.

Marques CM, Vasquez-Kool J, Carocha VJ, Ferreira JG, O'Malley DM, Liu B-H, Sederoff R. 1999. Genetic dissection of vegetative propagation traits in Eucalyptus tereticornis and E. globulus. Theor Appl Genet 99: 936-946.

Meilan R, Auerbach DJ, Ma C, DiFazio SP, Strauss SH. 2002. Stability of herbicide resistance and GUS expression in transgenic hybrid poplars (Populus sp.) during several years of field trials and vegetative propagation. Hortscience 37: 277-280.

Mencuccini M, Martinez-Vilalta J, Hamid HA, Korakaki E, Vanderklein D. 2007. Evidence for age- and size-mediated controls of tree growth from grafting studies. Tree Physiol 27: 463473.

Mitton JB, Grant MC. 1996. Genetic variation and the natural history of quaking aspen. Bioscience 46: 25-31.

Morgante M, Salamini F. 2003. From plant genomics to breeding practice. Curr Opin Biotechnol 14: 214-219.

Morreel K, Goeminne G, Storme V, Sterck L, Ralph J, Coppieters W, Breyne P, Steenackers M, Georges M, Messens E, et al. 2006. Genetical metabolomics of flavonoid biosynthesis in Populus: A case study. Plant J 47: 224-237.

Myburg AA. 2001. "Genetic architecture of hybrid fitness and wood quality traits in a wide interspecific cross of Eucalyptus tree species." PhD thesis, North Carolina State University, Raleigh.

Myburg AA, Griffin AR, Sederoff RR, Whetten RW. 2003. Comparative genetic linkage maps of Eucalyptus grandis, Eucalyptus globulus and their $\mathrm{F}_{1}$ hybrid based on a double pseudo-backcross mapping approach. Theor Appl Genet 107: $1028-1042$.

Myburg AA, Vogl C, Griffin AR, Sederoff RR, Whetten RW. 2004. Genetics of postzygotic isolation in eucalyptus: Whole-genome analysis of barriers to introgression in a wide interspecific cross of Eucalyptus grandis and E. globulus. Genetics 166: 14051418.

Myburg AA, Grattapaglia D, Tuskan GA, Schmutz J, Barry K, Bristow J. 2008. The Eucalyptus genome network. Sequencing the Eucalyptus genome: Genomic resources for renewable energy and fiber production (Plant and Animal Genome XVI Conference W195, January 12-16, San Diego).

Neale DB. 2007. Genomics to tree breeding and forest health. Curr Opin Genet Dev 17: 539-544.

Neale DB, Ingvarsson PK. 2008. Population, quantitative and comparative genomics of adaptation in forest trees. Curr Opin Plant Biol 11: 149-155.

Neale DB, Savolainen O. 2004. Association genetics of complex traits in conifers. Trends Plant Sci 9: 325-330.

Newcombe G, Bradshaw HD Jr, Chastagner GA, Stettler RF. 1996. A major gene for resistance to Melampsora medusae f.sp. deltoidae in a hybrid poplar pedigree. Phytopathology 86: 87-94.

Novaes E, Drost DR, Farmerie WG, Pappas GJ Jr, Grattapaglia D, Sederoff R, Kirst M. 2008. High-throughput gene and SNP discovery in Eucalyptus grandis, an uncharacterized genome. BMC Genomics 9: 312.

NSF-GLPEP. 2007. NSF Genomics of loblolly pine embryogenesis project (http://compbio.dfci.harvard.edu/cgi-bin/tgi/gimain. pl?gudb=pine).

O'Malley DM, Grattapaglia D, Chaparro JX, Wilcox PL, Amerson HV, Liu B-H, Whetten R, McKeand S, Kuhlman EG, McCord S, et al. 1996. Molecular markers, forest genetics and tree breeding. In Genomes of plants and animals: 21st Genetics Symposium (ed. JP Gustafson and RB Flavell), pp 87-102. Plenum, New York.

Parelle J, Zapater M, Scotti-Saintagne C, Kremer A, Jolivet Y, Dreyer E, Brendel O. 2007. Quantitative trait loci of tolerance to waterlogging in a European oak (Quercus robur L.): 
Physiological relevance and temporal effect patterns. Plant Cell Environ 30: 422-434.

Paux E, Carocha V, Marques C, Mendes de Sousa A, Borralho N, Sivadon P, Grima-Pettenati J. 2005. Transcript profiling of Eucalyptus xylem genes during tension wood formation. New Phytol 167: 89-100.

Plomion C, Durel C-E, O'Malley DM. 1996. Genetic dissection of height in maritime pine seedlings raised under accelerated growth conditions. Theor Appl Genet 93: 849-858.

Plomion C, Chagne D, Pot D, Kumar S, Wilcox P, Burdon R, Prat D, Peterson DG, Pavia J, Chaumeil P, et al. 2007. The pines. In Genome mapping and molecular breeding in plants: Forest trees (ed. CR Kole), Vol. 7, pp. 29-78. Springer, Heidelberg.

Poke FS, Vaillancourt RE, Potts BM, Reid JB. 2005. Genomic research in Eucalyptus. Genetica 125: 79-101.

Qui Y-L, Li L, Wang B, Chen Z, Dombrovska O, Lee J, Kent L, Li R, Jobson RW, Hendry TA, et al. 2007. A nonflowering land plant phylogeny inferred from nucleotide sequences of seven chloroplast mitochondrial and nuclear genes. Int J Plant Sci 168: 691-708.

Rae AM, Tricker PJ, Bunn SM, Taylor G. 2007. Adaptation of tree growth to elevated $\mathrm{CO}_{2}$ : Quantitative trait loci for biomass in Populus. New Phytol 175: 59-69.

Rafalski A. 2002. Applications of single nucleotide polymorphisms in crop genetics. Curr Opin Plant Biol 5: 94-100.

Ralph J, MacKay J, Hatfield R, Whetten RW, O'Malley DM, Sederoff RR. 1997 Abnormal lignin in a loblolly pine mutant. Science 277: 235-239.

Ralph S, Oddy C, Cooper D, Yueh H, Jancsik S, Kolosova N, Phillipe RN, Aeschliman D, White R, Huber D, et al. 2006a. Genomics of hybrid poplar (Populus trichocarpa $\mathrm{x}$ deltoides) interacting with forest tent caterpillars (Malacosoma disstria): Normalized and full-length cDNA libraries, expressed sequence tags, and a cDNA microarray for the study of insectinduced defences in poplar. Mol Ecol 15: 1275-1297.

Ralph SG, Yueh H, Friedmann M, Aeschliman D, Zeznik JA, Nelson CC, Butterfield YSN, Kirkpatrick R, Liu J, Jones SJ, et al. 2006b. Conifer defence against insects: Microarray gene expression profiling of Sitka spruce (Picea sitchensis) induced by mechanical wounding or feeding by spruce budworms (Choristoneura occidentalis) or white pine weevils (Pissodes strobi) reveals large-scale changes of the host transcriptome. Plant Cell Environ 29: 1545-1570.

Remington DL, O'Malley DM. 2000. Whole-genome characterization of embryonic stage inbreeding depression in a selfed loblolly pine family. Genetics 155: 337-348.

Schadt EE, Monks SA, Drake TA, Lusis AJ, Che N, Colinayo V, Ruff TG, Milligan SB, Lamb JR, Cavet G, et al. 2003. Genetics of gene expression surveyed in maize, mouse and man. Nature 422: 297-302.

Schimleck LR, Raymond CA, Beadle CL, Downes GM, Kube PD, French J. 2000. Application of NIR spectroscopy to forest research. Appita J 53: 458-464.

Schmidt M, Schneider-Poetsch HA. 2002. The evolution of gymnosperms redrawn by phytochrome genes: The Gnetales appear at the base of the gymnosperms. J Mol Evol 54: 715-724.

Schmidt A, Doudrick RL, Heslop-Harrison JS, Schmidt T. 2000. The contribution of short repeats of low sequence complexity to large conifer genomes Theor Appl Genet 101: 7-14.

Schrader J, Moyle R, Bhalerao R, Hertzberg M, Lundeberg J, Nilsson P, Bhalerao RP. 2004. Cambial meristem dormancy in trees involves extensive remodeling of the transcriptome. Plant J 40: $173-187$.

Sewell MM, Bassoni DL, Megraw RA, Wheeler NC, Neale DB. 2000. Identification of QTLs influencing wood property traits in loblolly pine (Pinus taeda L.). I. Physical wood properties. Theor Appl Genet 101: 1273-1281.

Sewell MM, Davis MF, Tuskan GA, Wheeler NC, Elam CC, Bassoni DL, Neale DB. 2002. Identification of QTLs influencing wood property traits in loblolly pine (Pinus taeda L.). II. Chemical wood properties. Theor Appl Genet 104: 214-222.

Spokevicius AV, Southerton SG, Colleen P, MacMillan CP, Qiu D, Gan S, Josquin FG, Tibbits JFG, Moran GF, Bossinger G.
2007. $\beta$-tubulin affects cellulose microfibril orientation in plant secondary fibre cell walls. Plant J 51: 717-726.

Stasolla C, Bozhkov PV, Chu T-M, van Zyl L, Egertsdotter U, Suarez MF, Craig D, Wolfinger RD, von Arnold S, Sederoff RR. 2004. A transcriptional pathway during somatic embryogenesis in gymnosperms. Tree Physiol 24: 1073-1085.

Steiner KC, Carlson JE, Eds. 2004. Restoration of American chestnut to forest lands. Pennsylvania State University School of Forest Resources, University Park, PA.

Sterky F, Regan S, Karlsson J, Hertzberg M, Rohde A, Holmberg A, Amini B, Bhalerao R, Larsson M, Villarroel R, et al. 1998. Gene discovery in the wood-forming tissues of poplar: Analysis of 5,692 expressed sequence tags. Proc Natl Acad Sci 95: 13330-13335.

Sterky F, Bhalerao RR, Unneberg P, Segerman B, Nilsson P, Brunner AM, Charbonnel-Campaa L, Lindvall JJ, Tandre K, Strauss SH, et al. 2004. A Populus EST resource for plant functional genomics. Proc Natl Acad Sci 101: 13951-13956.

Stirling B, Newcombe G, Vrebalov J, Bosdet I, Bradshaw HD. 2001. Suppressed recombination around the MXC3 locus, a major gene for resistance to poplar leaf rust. Theor Appl Genet 103: 1129-1137.

Strauss SH, Lande R, Namkoong G. 1992. Limitations of molecular marker-aided selection in forest tree breeding. Can J Forest Res 22: 1050-1061.

Strauss SH, Rottman WH, Brunner AM, Shephard L. 1995. Genetic engineering of reproductive sterility in forest trees. Mol Breed 1: 5-26.

Street NR, Skogstrom O, Sjodin A, Tucker J, Rodriguez-Acosta M, Nilsson P, Jansson S, Taylor G. 2006. The genetics and genomics of the drought response in Populus. Plant J 48: 321-341.

Taylor G. 2002. Populus: Arabidopsis for forestry. Do we need a model tree? Ann Bot 90: 681-689.

Thumma BR, Nolan MR, Evans R, Moran GF. 2005. Polymorphisms in cinnamoyl CoA reductase (CCR) are associated with variation in microfibril angle in Eucalyptus spp. Genetics 171: $1257-1265$.

Tulsieram LK, Glaubitz JC, Kiss G, Carlson JE. 1992. Single tree genetic linkage mapping in conifers using haploid DNA from megagametophytes. Bio-Technology 10: 686-690.

Tuskan GA, DiFazio S, Jansson S, Bohlmann J, Grigoriev I, Hellsten U, Putnam N, Ralph S, Rombauts S, Salamov A, et al. 2006. The genome of black cottonwood, Populus trichocarpa (Torr. and Gray). Science 313: 1596-1604.

Ukrainetz NK, Ritland K, Mansfield SD. 2007. Identification of quantitative trait loci for wood quality and growth across eight full-sib coastal Douglas-fir families. Tree Genet Genomes 4: 159-170.

Van Beveren KS, Spokevicius AV, Tibbits J, Qing W, Bossinger G. 2006. Transformation of cambial tissue in vivo provides an efficient means for induced somatic sector analysis and gene testing in stems of woody plant species. Funct Plant Biol 33: 629-638.

Van Zyl LM, Bozhkov P, Clapham D, Sederoff RR, von Arnold S. 2002. Up, down and up again is a signature global gene expression pattern at the beginning of gymnosperm embryogenesis. Gene Expr Patterns 3: 83-91.

Verhaegen D, Plomion C, Gion J-M, Poitel M, Costa P, Kremer A. 1997. Quantitative trait dissection analysis in Eucalyptus using RAPD markers. 1. Detection of QTL in interspecific hybrid progeny, stability of QTL expression across different ages. Theor Appl Genet 95: 597-608.

Wang MB, Waterhouse PM. 2002. Application of gene silencing in plants. Curr Opin Plant Biol 5: 146-150.

Watkinson JI, Sioson AA, Vasquez-Robinet C, Shukla M, Ellis M, Heath LS, Ramakrishnan N, Chevone B, Watson LT, Egertsdotter U, et al. 2003. Photosynthetic acclimation is reflected in specific patterns of gene expression in drought-stressed loblolly pine. Plant Physiol 133: 1702-1716.

Wayne ML, McIntyre LM. 2002. Combining mapping and arraying: An approach to candidate gene identification. Proc Natl Acad Sci 99: 14903-14906.

Wheeler N, Sederoff R. 2009. Role of genomics in the restoration 
of the American chestnut. Tree Genet Genomes 5: 181-187.

White TL, Adams WT, Neale DB. 2007. Forest genetics. CAB International, Cambridge, MA.

Whitham TG, Bailey JK, Schweitzer JA, Shuster SM, Bangert RK, LeRoy CJ, Lonsdorf EV, Allan GJ, DiFazio SP, Potts BM, et al. 2006. A framework for community and ecosystem genetics: From genes to ecosystems. Nat Rev Genet 7: 510-523.

Wicker T, Schlagenhauf E, Graner A, Close TJ, Keller B, Stein N. 2006. 454 sequencing put to the test using the complex genome of barley. BMC Genomics 7: 275.

Wilcox PL, Amerson HV, Kuhlman EG, Liu B-H, O’Malley DM, Sederoff RR. 1966. Detection of a major gene for resistance to fusiform rust disease in loblolly pine by genomic mapping. Proc Natl Acad Sci 93: 3859-3864.

Wu RL. 1998. Genetic mapping of QTLs affecting tree growth and architecture in Populus: Implication for ideotype breeding. Theor Appl Genet 96: 447-457.

Wu RL, Remington DL, MacKay JJ, McKeand SE, O'Malley DM. 1999. Average effect of a mutation in lignin biosynthesis in loblolly pine. Theor Appl Genet 99: 705-710.

Wullschleger SD, Tuskan GA, DiFazio SP. 2002. Genomics and the tree physiologist. Tree Physiol 22: 1273-1276.
Yang SH, Loopstra CA. 2005. Seasonal variation in gene expression for loblolly pines (Pinus taeda) from different geographical regions. Tree Physiol 25: 1063-1073.

Yang J, Park S, Kamdem DP, Keathley DE, Retzel E, Paule C, Kapur V, Han K-H. 2003. Novel gene expression profiles define the metabolic and physiological processes characteristic of wood and its extractive formation in a hardwood tree species, Robinia pseudoacacia. Plant Mol Biol 52: 935-956.

Yeh TF, Yamada T, Capanema E, Chang H-M, Chiang V, Kadla JF. 2005. Rapid screening of wood chemical component variations using transmittance near-infrared spectroscopy. J Agric Food Chem 53: 3328-3332.

Yvert G, Brem RB, Whittle J, Akey JM, Foss E, Smith EN, Mackelprang R, Kruglyak L. 2003. Trans-acting regulatory variation in Saccharomyces cerevisiae and the role of transcription factors. Nat Genet 35: 57-64.

Zhong R, Lee C, Zhou J, McCarthy RL, Ye Z-H. 2008. A battery of transcription factors involved in the regulation of secondary cell wall biosynthesis in Arabidopsis. Plant Cell 20: 27632782.

Zobel BJ, Talbert J. 1984. Applied forest tree improvement. Wiley, New York. 


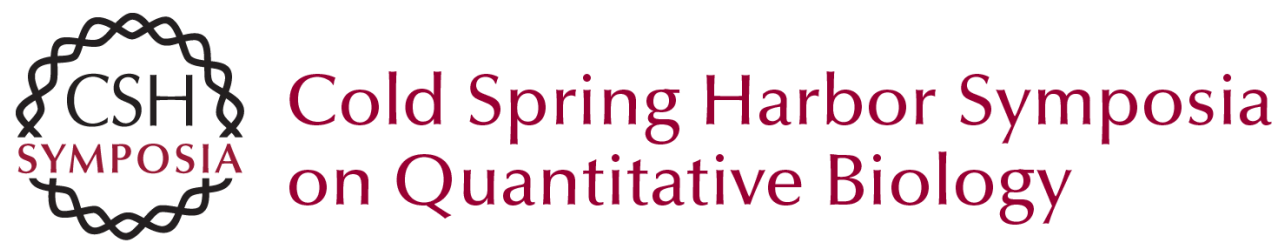

\title{
Genomics, Domestication, and Evolution of Forest Trees
}

\author{
R. Sederoff, A. Myburg and M. Kirst
}

Cold Spring Harb Symp Quant Biol 2009 74: 303-317 originally published online April 7, 2010 Access the most recent version at doi:10.1101/sqb.2009.74.040

References This article cites 146 articles, 33 of which can be accessed free at: http://symposium.cshlp.org/content/74/303.full.html\#ref-list-1

License

Email Alerting Receive free email alerts when new articles cite this article - sign up in the box at the Service top right corner of the article or click here.

To subscribe to Cold Spring Harbor Symposia on Quantitative Biology go to:

http://symposium.cshlp.org/subscriptions 